\title{
PATIENT ASSESSMENT OF INTERPERSONAL QUALITY IN OUTPATIENT INSTALLATION CLINIC HOSPITAL EYE UNDAAN
}

\author{
Finda Muthia Hanum \\ Depertment of Health Policy and Administration \\ Faculty of Public Health, Airlangga University, Surabaya, Indonesia \\ Correspondence Address: Finda Muthia Hanum \\ E-mail: muthiafinda@gmail.com
}

\begin{abstract}
The mission of Undaan Eye Hospital is to provide high quality and affordable eye health service. However, some problems which indicate customer's dissatisfaction are still found, including the amount of customer complaints which hasn't reached the target set by hospital which is zero complaint. Based on Customer Complaint Report of Undaan Eye Hospital, most complaints are caused by communication problem. The aim of this study is to analyze the interpersonal quality of Polyclinic of Outpatient Clinic of Undaan Eye Hospital which consists of respect, confidentiality, courtesy, responsiveness, dan empathy. This study is using descriptive and cross-sectional design and conducted to 82 people who are representing the outpatients and proceeded using simple random sampling method. The data were obtained by interviewing respondents using questionnaire. The data is analyzed using quantitative method and presented in tables. The result of the study shows that most of the respondents which includes 63,41\% respondents feeling a little satisfied with interpersonal quality in Polyclinic of Outpatient Clinic of Undaan Eye Hospital. The result of the study shows that most of respondents feeling satisfied with respect, courtesy, confidentiality, and empathy of the service, however they are feeling a little satisfied with responsiveness of the service. Therefore, the hospital needs to improve their quality especially in responsiveness aspect by reducing patient wait times, and maintaining the quality of the aspects which have good ratings of patient satisfaction.
\end{abstract}

Keywords: interpersonal quality, outpatient clinic, patient satisfaction

\begin{abstract}
ABSTRAK
Rumah Sakit Mata Undaan memiliki misi untuk memberikan pelayanan kesehatan mata yang bermutu tinggi dan terjangkau. Akan tetapi, masih ditemukan masalah yang menunjukkan bahwa pelayanan belum memenuhi harapan pelanggan seperti jumlah keluhan pelanggan yang belum mencapai target rumah sakit yaitu 0 keluhan. Berdasarkan Laporan Keluhan Pelanggan Rumah Sakit Mata Undaan Tahun 2016, penyebab keluhan pelanggan terbanyak adalah komunikasi. Tujuan dari penelitian ini adalah untuk menganalisis interpersonal quality Instalasi Rawat Jalan Poliklinik Rumah Sakit Mata Undaan yang meliputi respect, confidentiality, courtesy, responsiveness, dan empathy. Penelitian ini adalah penelitian deskriptif dengan rancang bangun cross sectional. Besar sampel diperoleh berdasarkan rumus perhitungan simple random sampling, sehingga diperoleh sampel penelitian sebanyak 82 orang. Pengambilan data dilakukan dengan melakukan wawancara kepada responden dengan alat bantu kuesioner. Data dianalisis secara kuantitatif dan disajikan dalam bentuk tabel. Hasil penelitian menunjukkan bahwa mayoritas responden yakni sebanyak $63,41 \%$ responden merasa sedikit puas terhadap interpersonal quality Instalasi Rawat Jalan Poliklinik Rumah Sakit Mata Undaan. Hasil penelitian menunjukkan mayoritas responden merasa puas terhadap aspek respect, confidentiality, courtesy, dan empathy, namun merasa sedikit puas terhadap aspek responsiveness. Oleh karena itu, perlu dilakukan peningkatan mutu terutama pada aspek responsiveness yaitu dengan mempercepat lama waktu tunggu pelayanan, sedangkan aspek yang telah mencapai kepuasan pelanggan perlu dipertahankan.
\end{abstract}

Kata Kunci: interpersonal quality, kepuasan pelanggan, instalasi rawat jalan

\section{INTRODUCTION}

Quality health Services is a health service that can create satisfaction in every customer who get service. According to (Singh, 1989), patient satisfaction is the combined index of evaluative opinions on the quality of medical services provided by doctors, nurses and other related personnel. Patient satisfaction is a measure of the quality of health care, it is important because the patient satisfaction gives 
information to the service provider about its success in meeting the needs of customers (Yegon, 2011).

The satisfaction of the hospital's services are subjective and each patient has a different perception and is not necessarily the same as the standard of service prescribed by the hospital. (Alrubaiee, 2011) mentions that after receiving service, patient satisfaction was strongly influenced by variables relating to communication between doctors and patients, but in general the satisfaction was influenced by age and Patient's functional status.

(Thawesaengskulthai, N., Wongrukmit, P., Dahlgaard, 2015) Explain that customer satisfaction can bring beneficial outcomes to hospitals with marked patient retention, positive word of mouth, and more profit. High. If the patient is satisfied with the service provided by a hospital, then when they need the service product again, they will choose to come to the hospital for the second time and so on. Patients who are satisfied with the hospital's services are also likely to give recommendations to people they know. However, according to (Ghoniyah, 2012), in case of dissatisfaction, there are at least four possibilities that can occur in response from customers, among others, not doing anything; Stop buying products and or delivering word of mouth to your family, friends, and nearby people; Convey complaints directly and or solicit compensation to the company; and complaining through mass media, to consumer institutions or related government agencies, or prosecute producers legally.

Vision and blindness disorders that are still a health problem in Indonesia certainly affect the utilization of eye health services including the Undaan Eye Hospital. As a hospital that has stood since eighty three years ago, Undaan Mata Hospital has a vision to be the main choice Eye Hospital of the community in health care. One of the mission of the hospital is to provide high quality and safe eye health services. This high quality and safe healthcare service should be translated as a service based on customer's expectations and needs so that it can satisfy customers.

According to the Undaan year Hospital's customer complaint report 2016, the number of complaints received by Undaan Eye Hospital reached 21 complaints. It shows that the number of customer complaints has not reached the hospital target of 0 complaints. The zero complaint has not been achieved, indicating that the patient is still not fully satisfied with the service provided and the quality of service has not been in accordance with the needs and expectations of the patient. According to the Undaan year Hospital's customer complaint report 2016, the most common cause of customer complaints is communication. This suggests that customers are still experiencing obstacles in communicating with service providers as well as interpersonal relationships between service providers and customers are still not well developed.

Preliminary surveys are also conducted on 24 respondents of the service users at the outpatient installation clinic Mata Undaan to find out related services that have been deemed not satisfactory or not optimal. Based on the results of the survey, the length of waiting time and the area and convenience of parking is the most widely mentioned aspect of service by respondents.

One factor that can cause patient dissatisfaction is interpersonal quality. (Donabedian, 1988) divides the quality of health services into three components where one of its components is interpersonal quality. Interpersonal relationships have a vital role in healthcare services (Donabedian, 1988) . In health care, interpersonal relationships relate to the interaction between the provider and the patient (Kiguli, J., Ekirapa-Kiracho, E., Okui, O., Mutebi, A., MacGregor, H., Pariyo, 2009). Through interpersonal relationships, the patient can communicate the information necessary to obtain the 
diagnosis and also the options needed to choose the most appropriate treatment method (Donabedian, 1988). Through the exchange of this information, the doctor can provide information about the disease and its management and motivate patients to actively cooperate in the treatment (Donabedian, 1988) . Therefore, interpersonal Relationship management determines the success of technical treatment (Donabedian, 1988) . According to (Brown, L.D., Franco, L.M., Rafeh, N., Hatzell, 1998), good interpersonal relationships can foster trust and credibility, which can be gained through respect, confidentiality, courtesy, responsiveness, and empathy.

Therefore, the purpose of this research is to analyse interpersonal quality outpatient installation Undaan Eye Hospital which includes respect, confidentiality, courtesy, responsiveness, and empathy.

\section{METHODS}

This research is a descriptive study with a cross sectional design. The population in this study is the entire patient installation of outpatient hospital eye Undaan. A large population determination is derived from the average estimate of a polyclinic per month outpatient visit in 2016, amounting to 4000 patient visits. Large samples were obtained based on simple random sampling calculation formula, resulting in a sample of research of 82 people. The patients who can become respondents in this study are patients with the following criteria; 1) Patients who use services in the outpatient installation Clinic Eye Undaan, 2) patients are willing to be research respondents and willing to fill out questionnaires, 3) patients are conscious and able to communicate well.

The data collection instrument used is a questionnaire sheet that is used as a guide for conducting interviews against respondents. The research questionnaire uses an assessment with a scale of 1-7 with answers options very dissatisfied, dissatisfied, less satisfied, ordinary, less satisfied, satisfied, and very satisfied. After the primary data is accumulated, the data processing is quantitatively and then presented in the form of tables. This research has obtained a description of the passing of the Ethics Commission FKM No: 381-KEPK.

\section{RESULT}

\section{Interpersonal Quality}

Assessment of interpersonal quality installation of outpatient hospital eye Undaan is obtained through the variables respect, confidentiality, courtesy, responsiveness, and empathy. The following are the calculation results of each variable.

\section{Characteristics of respondents demographics}

Table 1. Distribution characteristics demographic patient installation patient on Outpatient Hospital eye Undaan in 2017

\section{Characteristics of respondents demographics}

\begin{tabular}{lrr}
\hline Gender & & \\
\hline Male & 14 & 17,07 \\
\hline Female & 68 & 82,93 \\
\hline Amount & 82 & 100,00 \\
\hline Age & & \\
\hline $15-34$ & 9 & 10,98 \\
\hline $35-54$ & 27 & 32,92 \\
\hline $55-74$ & 42 & 51,22 \\
\hline Amount & 82 & 100,00 \\
\hline Education Level & & \\
\hline No School & 8 & 9,76 \\
\hline Graduated SD & 14 & 17,07 \\
\hline Graduate SCHOOL & 19 & 23,17 \\
\hline$\quad$ Graduated SMA & 27 & 32,93 \\
\hline$\quad$ Graduate School & 14 & 17,07 \\
\hline Amount & 82 & 100,00 \\
\hline Job & & \\
\hline$\quad$ Not Work & 52 & 63,42 \\
\hline$\quad$ Work & 30 & 36,58 \\
\hline Amount & 82 & 100,00 \\
\hline
\end{tabular}




\begin{tabular}{lrr}
\hline $\begin{array}{c}\text { Characteristics of } \\
\text { respondents } \\
\text { demographics }\end{array}$ & n & $\%$ \\
\hline Income Level & & \\
\hline$<1.500 .000$ & 60 & 73,17 \\
\hline $1.500 .000-3.000 .000$ & 11 & 13,41 \\
\hline$>3.000 .000-6.000 .000$ & 10 & 12,20 \\
\hline$>4.500 .000-6.000 .000$ & 1 & 1,22 \\
\hline$>6.000 .000$ & 0 & 0,00 \\
\hline Amount & 82 & 100,00 \\
\hline
\end{tabular}

According to Table 1 it is showed that most of the respondents in female gender research are $82.93 \%$ or as many as 68 respondents. Most of the respondents were $51.22 \%$ or 42 people aged 55-74 years or included in elderly groups. Most of the respondents were $32.93 \%$ or 27 people have the last degree of graduate school. Most of the respondents were $63.42 \%$ or 52 people did not work. Most of the respondents were $73.17 \%$ or 60 people have a revenue rate of less than IDR 1,500,000

\section{Respect}

Based on Table 2, it is showed that most of the customers are $84.15 \%$ satisfied with the respect aspect of hospital outpatient installation eye Undaan. Although overall customers feel satisfied with the respect aspect, but when viewed in table 3, each item assessment aspect respect which consists of a doctor's willingness to always give the patient the opportunity to ask and Doctor's willingness to ask for the opinions and approval of the patient in the decision making, the average score is 5.88 and 5.98 which means that customers feel less satisfied with both items of the assessment.

\section{Confidentiality}

Based on Table 2, it is known that most of the customers are $96.34 \%$ satisfied with the confidentiality aspect of Undaan Eye Hospital outpatient installation. The Confidentiality aspect assessment consists of one assessment item which is the willingness of doctors and nurses to maintain the confidentiality of the patient's information. According to table 3 , it is important that the aspects of the willingness of doctors and nurses to maintain the confidentiality of the patient's information get an average score of 6.00 which means that most of the respondents were satisfied.

\section{Courtesy}

Based on Table 2 It is known that most of the customers are as much as $86.59 \%$ overall feel satisfied to the courtesy aspect of the Outpatient installation Clinic Hospital Mata Undaan. Although overall customers feel satisfied about the courtesy aspect, but when viewed in table 3 , each item is a courtesy aspect assessment consisting of friendliness and politeness of doctors and nurses in providing service, friendliness and Politeness registration officers in providing service, and friendliness and courtesy of the pharmacy clerk in providing services, all three get an average score i.e. each 5.98 which means that the customer feels a little satisfied against the third Such assessment items.

\section{Responsiveness}

Based on Table 2, it is known that overall, the majority of the customers are $43.90 \%$ less satisfied with the responsiveness aspect of hospital's outpatient installation clinic Mata Undaan. This means that the responsiveness aspect in the service has not been carried out optimally so that customers are still not fully satisfied.

Based on Table 3, it is known that the three items of appraisal aspect of the response consist of doctors and nurses in response to patient complaints, readiness of officers to assist patients, ease of service procedures, Get the average score of each 5.91, 5.91, and 5.60 which means that customers feel a little satisfied with these three valuation Items. 
Table 2. Results of Interpersonal assessment of customer's outpatient installation Polyclinic Eye Hospital Undaan year 2017

\begin{tabular}{|c|c|c|c|c|c|c|c|c|c|c|}
\hline \multirow{2}{*}{ Value } & \multicolumn{2}{|c|}{ Respect } & \multicolumn{2}{|c|}{ Confidentiality } & \multicolumn{2}{|c|}{ Courtesy } & \multicolumn{2}{|c|}{ Responsiveness } & \multicolumn{2}{|c|}{ Empathy } \\
\hline & $\mathbf{n}$ & $\%$ & $\mathbf{n}$ & $\%$ & $\mathbf{n}$ & $\%$ & $\mathbf{n}$ & $\%$ & $\mathrm{n}$ & $\%$ \\
\hline $\begin{array}{l}\text { Very } \\
\text { dissatisfie } \\
\text { d }\end{array}$ & 0 & 0,00 & 0 & 0,00 & 0 & 0,00 & 0 & 0,00 & 0 & 0,00 \\
\hline Not & 0 & 0,00 & 0 & 0,00 & 0 & 0,00 & 0 & 0,00 & 0 & 0,00 \\
\hline Satisfied & 0 & 0 & 0 & 0 & 0 & 0 & 1 & 1,22 & 1 & 1,22 \\
\hline $\begin{array}{l}\text { Less } \\
\text { satisfied }\end{array}$ & 4 & 4,88 & 1 & 1,22 & 1 & 1,22 & 14 & 17,07 & 1 & 1,22 \\
\hline $\begin{array}{l}\text { The } \\
\text { ordinary }\end{array}$ & 5 & 6,10 & 0 & 0,00 & 8 & 9,76 & 36 & 43,90 & 3 & 3,66 \\
\hline $\begin{array}{l}\text { A bit } \\
\text { satisfied }\end{array}$ & 69 & 84,15 & 79 & 96,34 & 71 & 86,59 & 31 & 37,80 & 75 & 91,46 \\
\hline Satisfied & 4 & 4,88 & 2 & 2,44 & 1 & 1,22 & 0 & 1,22 & 2 & 2,44 \\
\hline Amount & 82 & 100,00 & 82 & 100,00 & 82 & 100,00 & 82 & 100,00 & 82 & 100,00 \\
\hline
\end{tabular}

Table 3. Average Interpersonal assessment Quality of outpatient installation clinic of Hospital eye Undaan year 2017

\section{Item Valuation}

Value

Total Average

$$
\begin{array}{llllllll}
(2) & (3) & \text { (4) } & \text { (5) } & \text { (6) } & \text { (7) } & \text { Score } & \text { Score }
\end{array}
$$

$\begin{array}{llllllllll}\text { A doctor's willingness to always } \mathrm{n} & 0 & 3 & 3 & 0 & 71 & 5 & 482 & 5,88\end{array}$ $\begin{array}{llllllll}\text { give the patient the opportunity to } & \text { Skor } & 0 & 9 & 12 & 0 & 426 & 35\end{array}$ ask.

\begin{tabular}{llllllllll}
\hline A doctor's willingness to ask for & $\mathrm{n}$ & 0 & 1 & 0 & 3 & 74 & 4 & 490 & 5,98 \\
\cline { 2 - 6 } $\begin{array}{l}\text { opinion and patient approval in } \\
\text { decision making. }\end{array}$ & Skor & 0 & 3 & 0 & 15 & 444 & 28 & &
\end{tabular}

$\begin{array}{llllllllllll}\text { The willingness } & \text { of doctors } \\ \text { nurses to } & \text { maintain } & \text { the } & \text { S } & 0 & 0 & 1 & 0 & 79 & 2 \\ \text { Skor } & 0 & 0 & 4 & 0 & 474 & 14 & 6,00\end{array}$
confidentiality of patient information well.

\begin{tabular}{llllllllll}
\hline Hospitality and politeness doctors & $\mathrm{n}$ & 0 & 0 & 1 & 4 & 73 & 4 & \multirow{2}{*}{490} & 5,98 \\
\cline { 2 - 7 } and nurses in providing services & Skor & 0 & 0 & 4 & 20 & 438 & 28 & &
\end{tabular}
\begin{tabular}{llllllllll}
\hline $\begin{array}{l}\text { Hospitality and Courtesy Officer } \\
\text { registration in providing service. }\end{array}$ & $\mathrm{n}$ & 0 & 0 & 1 & 3 & 75 & 3 & 490 & 5,98 \\
\cline { 2 - 6 } & Skor & 0 & 0 & 4 & 15 & 450 & 21
\end{tabular}

\begin{tabular}{llllllllll}
\hline Hospitality and politeness of the & $\mathrm{n}$ & 0 & 0 & 1 & 2 & 77 & 2 & 490 & 5,98
\end{tabular} $\begin{array}{lllllllll}\text { pharmacy officer in providing } & \text { Skor } & 0 & 0 & 4 & 10 & 462 & 14\end{array}$ service.

\begin{tabular}{|c|c|c|c|c|c|c|c|c|c|}
\hline \multirow{2}{*}{$\begin{array}{l}\text { Responses to doctors and nurses in } \\
\text { reaction to patient complaints. }\end{array}$} & $\mathrm{n}$ & 0 & 1 & 2 & 3 & 73 & 3 & \multirow[t]{2}{*}{485} & \multirow[t]{2}{*}{5,91} \\
\hline & Skor & 0 & 3 & 8 & 15 & 438 & 21 & & \\
\hline & $\mathrm{n}$ & 0 & 0 & 3 & 3 & 74 & 2 & 485 & 5,91 \\
\hline
\end{tabular}




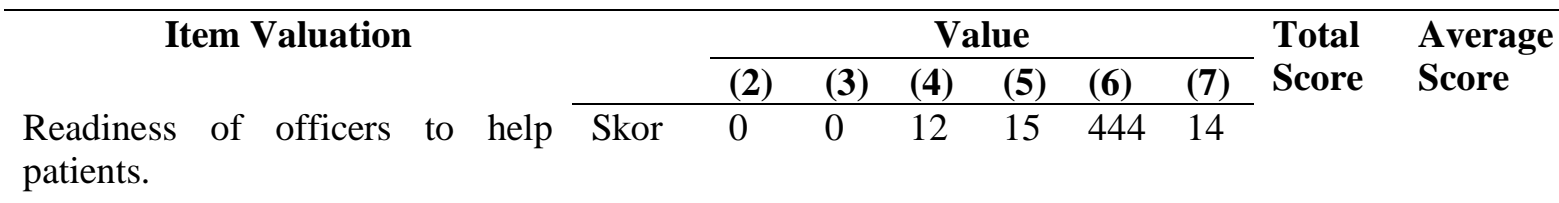

\begin{tabular}{|c|c|c|c|c|c|c|c|c|c|}
\hline \multirow[t]{2}{*}{ Ease of Service procedure } & $\mathrm{n}$ & 0 & 7 & 6 & 2 & 65 & 2 & \multirow[t]{2}{*}{459} & \multirow[t]{2}{*}{5,50} \\
\hline & Skor & 0 & 21 & 24 & 10 & 390 & 14 & & \\
\hline \multirow{2}{*}{ Long service waiting time. } & $\mathrm{n}$ & 1 & 17 & 15 & 17 & 32 & 0 & \multirow[t]{2}{*}{390} & \multirow[t]{2}{*}{4,76} \\
\hline & Skor & 2 & 51 & 60 & 85 & 192 & 0 & & \\
\hline \multirow{2}{*}{$\begin{array}{l}\text { The willingness of doctors and } \\
\text { nurses to give personal attention to } \\
\text { the patient. }\end{array}$} & $\mathrm{n}$ & 0 & 1 & 2 & 2 & 73 & 4 & \multirow[t]{2}{*}{487} & \multirow[t]{2}{*}{5,94} \\
\hline & Skor & 0 & 3 & 8 & 10 & 438 & 28 & & \\
\hline
\end{tabular}

\begin{tabular}{llllllllll}
\hline $\begin{array}{l}\text { The willingness of officers to listen } \\
\text { and help patients when needed. }\end{array}$ & $\mathrm{n}$ & 0 & 0 & 1 & 2 & 77 & 2 & 490 & 5,98 \\
\cline { 2 - 7 } & Skor & 0 & 0 & 4 & 10 & 462 & 14 & &
\end{tabular}

\section{Empathy}

Based on Table 2, it is known that most of the customers are $91.46 \%$ satisfied with the empathy aspect of the hospital's outpatient installation clinic Mata Undaan. While the customer is satisfied with the empathy aspect, however, when viewed in table 3, each of the empathy aspect assessment items consists of the

\section{DISCUSSION}

\section{Characteristics of respondents demographics}

Demographics are the science of human populations in terms of size, density, location, age, gender, race, livelihoods, and other statistics (Yoga, I.M.S., Warmika, 2013). Aspects of consumer demographics such as age, gender, education and employment can also affect consumer satisfaction (Saifulloh, 2014).

\section{Gender}

Gender factors cause the utilization of health services vary due to the level of human vulnerability caused by each gender. From the results of the study can be described that most of the respondents who utilize the service in the outpatient installation clinic Eye Undaan Women's willingness of the doctor and nurse to give personal attention to the patient. And willingness of officers to listen to and assist patients when needed, both get an average score of 5.94 and 5.98 which means that customers feel less satisfied with both items of the assessment. This indicates that both items of assessment have not been carried out optimally so that customers are still not fully satisfied.

gender is as much as $82.93 \%$ of the total respondents. The use of more health services is done by women because women have a greater incidence and risk of disease than men (Ruditya, A.N., Chalidyanto, 2015).

Age

From the results of the study can be concluded that respondents who utilize the service in the outpatient installation clinic Eye Undaan The majority are from the age group 55-64 and 65-74 which is an elderly group of age. The increasing age of a person, the more changes in the body system, namely the decline of various bodily functions (Rahmawati, 2010). Decreased physical function due to age increase will cause various health problems so that the utilization of health services will increase in this age group. 


\section{Education level}

The results of this study showed that the largest number of respondents who utilize the service in the outpatient installation Clinic Mata Undaan Hospital is a respondent who is a high school with a total of $32.93 \%$. Thus it can be concluded that the majority of respondents have a high level of education. There is a link between the level of education of one person and health care. According to (Handayani, 2012), the level of education is one of the factors affecting the utilization of health care by individuals. For the utilization of specialist health services, data on Switzerland, Denmark, and Canada shows there is an increase in the utilization of specialist health services in the community with higher levels of education (Feinstein, L., Sabates, R., Anderson, T.M., Sorhaindo, A., Hammond, 2006). In Switzerland, for example, higher levels of education have increased the utilization of specialist health services by $45 \%$ (Feinstein, L., Sabates, R., Anderson, T.M., Sorhaindo, A., Hammond, 2006) .

Explained that in previous research related differences in the affordability of specialist health services showed that people with lower levels of education tend to be less able to demonstrate Preference to healthcare services. It also shows that individuals with higher levels of education can access health services more effectively and prefer specialist health services than primary health care (Feinstein, L., Sabates, R., Anderson, T.M., Sorhaindo, A., Hammond, 2006) .

\section{Job}

From the research results can be known that most of the respondents who utilize the service at the outpatient installation Clinic Mata Undaan Hospital is a respondent who does not work with the number of respondents as much as $62.20 \%$. Many of the respondents who do not work can be caused because most of the respondents are elderly patients who belong to the age of no more productive. The further the age of a person over a productive age at a certain peak point, then his physical ability is increasingly diminishing which causes his working productivity to decline. In addition to age factors, many nonworking respondents can also result from illness or eye defects suffered. Eye health problems can decrease the productivity of their work (Lestari, S., 2013).

\section{Income level}

The income level illustrates the level and economic condition of a family (Ruditya, A.N., Chalidyanto, 2015). The ability of individuals or families to get health care can be seen from the level of its income. The majority of respondents who use the outpatient installation service of hospital Mata Undaan has a revenue level of less than Rp 1,500,000.00 or can be said the majority of respondents have a low income level. The availability of services for the participants of National health insurance is an attraction for the community to utilize the service in the outpatient installation clinic eye Undaan Although most customers have a level of income are lacking.

\section{Interpersonal Quality}

Interpersonal quality illustrates the characteristic of interaction between service providers and patients (Chang, J.T., Hays., R.D., Shekelle, P.G., MacLean, C.H., Solomon, D.H., Reuben, D.B., Roth, C.P., Kamberg, C.J., Adams, J., Young, R.T., Wenger, 2006). According to (Brown, L.D., Franco, L.M., Rafeh, N., Hatzell, 1998), good interpersonal relationships can foster trust and credibility that can be gained through respect, confidentiality, courtesy, responsiveness, and empathy. Interpersonal quality assessments on the outpatient installation clinic Mata Undaan Hospital is obtained by the average value of the five aspects of the assessment consisting of respect, confidentiality, courtesy, responsiveness, and empathy. 
Furthermore, the average value is grouped on highly dissatisfied, dissatisfied, less satisfied, ordinary, slightly satisfied, satisfied, and very satisfied categories.

The results showed that most of the respondents were $63.41 \%$ of respondents felt a little satisfied with the interpersonal quality of service on the outpatient installation Polyclinic Eye Undaan Hospital. A total of $34.15 \%$ of other respondents were satisfied and as many as $2.44 \%$ of the other respondents felt ordinary about the interpersonal quality of service on the outpatient installation of polyclinics Eye Undaan Hospital.

Based on Table 2, it is showed that no respondent feels very dissatisfied and dissatisfied with each of the indicators of quality interpersonal assessments of the outpatient installation Clinic Mata Undaan Hospital. The confidentiality aspect of the interpersonal quality assessment on the outpatient installation service of hospital Mata Undaan has the highest percentage in the satisfied category of $96.34 \%$. Overall it can be known that the respondent is satisfied with the interpersonal quality that covers aspects of respect, confidentiality, courtesy, responsiveness, and empathy on the service of outpatient installation of hospital Mata Undaan Clinic.

\section{Respect}

According to (Piligrimiene, Z., Rutelione, 2013) Respect is a form for the values, choices, and needs of the patient. Respect is the degree to which the patient is involved in the decision-making process and degrees to the extent that the service is given with care and respect for the values and expectations of the patient. Based on Table 2, it is known that the majority of customers are $84.15 \%$ satisfied with the respect of aspects of the outpatient installation Clinic Eye Undaan Hospital. Although overall customers feel satisfied with the respect aspect, but when viewed in table 3, each item assessment aspect respect which consists of a doctor's willingness to always give the patient the opportunity to ask and A doctor's willingness to ask for the opinions and approval of the patient in the decision-making, both of which received an average score of 5.88 and 5.98, meaning that the customer felt a little satisfied with the two items of the assessment.

A doctor's willingness to give patients the opportunity to ask questions is crucial. The meetings are ineffective because the communication that is only one direction is often an obstacle in communication between doctors and patients (Ismawati, 2009). The doctor felt that the patient was aware of the information given when the patient did not understand what the doctor was told (Ismawati, 2009) . Communication that does not go well will make the patient feel hesitant and reluctant to ask the doctor, the patient just follow what the Doctor delivered (Ismawati, 2009) . In the provision of medical services, the effective communication between doctors and patients is the expected condition so that doctors can conduct management of health problems with patients, based on the needs of patients (Fourianalistyawati, 2012).

A doctor's willingness to ask for opinion and patient approval in decision making is crucial. The patient's participation in the decision making process can also affect the success of the patient's treatment. This is in line with the concept of patient Centered Care (PCC), which is the concept of managing patients by referring and appreciating the individual patient including preferences/choices, requirements, values, and ensuring that all the clinical decision-making Have considered all the desired values of the patient (Rusmawati, 2016). All components of the hospital, including the Clinicis must implement the concept of PCC and mindset that the patient is the only patient that exists so that it is completely focused, and does not make the decision without involving the patient (Rusmawati, 2016) . 


\section{Confidentiality}

According to (Offei, A.K., Bannerman, C., Kyeremeh, 2004), confidentiality is the protection of customer information from Parties that are not expected to have access to such information. This includes conducting consultations with patients who uphold the protection of patient's privacy and maintain the confidentiality of information provided by the patient as well as the patient's illness except in cases where information Must be given to a healthcare provider or where the patient's consent has been obtained (Silva, 2000). Based on Table 2, it is known that the majority of customers are $96.34 \%$ satisfied with the confidentiality aspect of the Outpatient installation service Clinic Mata Undaan Hospital. According to table 3 , it is important to know that aspects of the willingness of doctors and nurses to maintain the confidentiality of the patient's information have an average score of 6.00 which means that the majority of respondents are satisfied with the aspect of doctor and nurse To maintain the confidentiality of patient information.

(Dewi, N., Susilowati, T., Nugroho, 2017) mentioned that every medical worker and medical personnel should maintain the confidentiality of medical record files included in it is medical secrets. The secret of medicine is anything related to the thing found by doctors and dentists in the course of treatment and recorded in the patient's medical records and is confidential (law RI No. 44 Year 2009 about hospitals Explanation of article 38 paragraph 1).

\section{Courtesy}

According to (Yarimoglu, 2014), courtesy is courtesy, respect, attentiveness, and friendliness of the officer, consideration of the patient's characteristics, hygiene and the rigor of appearance of the attendant. Customers expect service providers not only do technical work but also be attentive, polite, friendly, show respect, empathy, sensitivity, and kindness, and express their sense of sympathy for patients (Mosadeghrad, 2012).

Based on Table 2 it can be known that the majority of customers are $86.59 \%$ feel satisfied to the courtesy aspect of the Outpatient installation Clinic Hospital Mata Undaan. Although overall customers feel satisfied about the courtesy aspect, but when viewed in Table 3, each item is a courtesy aspect assessment consisting of friendliness and politeness of doctors and nurses in providing service, friendliness and Politeness registration officers in providing service, and friendliness and courtesy of the pharmacy clerk in providing services, all three get an average score i.e. each 5.98 which means that the customer feels a little satisfied against the third The assessment item.

Because the majority of customers have not been fully satisfied with the aspect of politeness and friendliness of service providers in providing services, the politeness and friendliness of service providers in providing services need to be further improved again. Politeness and hospitality provider of doctors, nurses, and other officers in providing services can be improved by always implementing $3 \mathrm{~S}$ (smiles, Greetings, Sapa) to all customers, serving customers with patience, as well as providing information to customers clearly. Politeness and hospitality in providing service is one of the factors that affects the quality of service services especially for those who interact with the officers (Ummah, A,R., Supriyanto, 2014).

\section{Responsiveness}

According to (Berry, L.L., Parasuraman, A., Zeithaml, 1994), responsiveness or responsiveness is a willingness to help customers and a willingness to serve customers well. Healthcare Respontanities relate to the speed of response provided by healthcare providers at patient's request.

Based on Table 2, it is known that overall the majority of the customers are 
$43.90 \%$ less satisfied with the responsiveness aspect of the hospital's outpatient installation clinic Mata Undaan. This means that the responsiveness aspect in the service has not been carried out optimally so that customers are still not fully satisfied.

According to Table 3 It can be noted that the response of doctors and nurses in responding to patients ' complaints is getting an average score of 5.91 which means that the majority of customers feel a little satisfied. This suggests that customers have not completely satisfied. This can happen because customers feel the responsiveness of doctors and nurses who are lacking in response to patient complaints, and doctors and nurses do not respond to the patient's complaint quickly.

According to Table 3 It can be noted that the readiness of the officer to help the patient get an average score of 5.91 which means that the majority of customers feel less satisfied. This suggests that customers have not completely satisfied. This can happen because the officer can not respond quickly to the patient's assistance.

According to Table 3 it can be noted that the ease of service procedure gets an average score of 5.60 which means that the majority of customers feel a little satisfied. This implied that customers have not completely satisfied. This can be due to the patient feels that the service procedure is too long or difficult to understand.

In addition, the assessment items of the old service waiting time get an average score of 4.76 which means customers feel dissatisfied. The patient's waiting time is one of the potential components causing dissatisfaction (Bustani, N.M., Rattu, A.J., Saerang, 2015). If the waiting time is long, it will reduce the patient's comfort and affect the patient's utility. The Undaan Eye Hospital needs to add the number of rooms, doctors, health workers, and equipment that support the service on the outpatient side to more handle the patient at the same time so that the time wait for faster service.

\section{Empathy}

According to (Berry, L.L., Parasuraman, A., Zeithaml, 1994), empathy is a sense of caring and individual attention given to customers. The dimension of empathy is the dimension that provides a great opportunity to create an unexpected service user service but it was given by the service provider (Handayani, 2016). Empathy is concerned with caring and personal attention to consumers, the ability to make contact with consumers, provide information so that consumers understand and understand the intent of service providers and the empowerment process of understanding To consumers and needs (Aziza, 2016).

Based on the results of the research, the majority of customers are $91.46 \%$ satisfied with the empathy aspect of the hospital's outpatient installation clinic Mata Undaan. Although overall customers are satisfied with the empathy aspect, but when viewed in table 3, each empathy aspect assessment item gets a slightly satisfied rating according to the majority of the customer.

According to Table 3 the willingness of doctors and nurses to pay personal attention to the patient and the willingness of the staff to listen to the average score is 5.94 which means that the customer feels a little satisfied with the valuation item. This can be caused by some patients who feel that the attention of individuals given by doctors and nurses by motivating patients, listening to patient complaints, and providing advice to the patient is still not fully satisfactory.

Based on Table 3 willingness to listen and help patients if required to get an average score of 5.98 which means that customers feel less satisfied with the valuation item. This can be caused by the concern of officers in listening and assisting the patient is not fully satisfactory. 


\section{CONCLUSION}

Overall it can be concluded that the respondent felt a little satisfied with the interpersonal quality on the outpatient installation service of hospital eye Undaan. The results showed that most customers were satisfied with the respect, confidentiality, courtesy, and empathy aspects, but felt a little satisfied with the responsiveness aspect. Assessment items that have the highest average score are the willingness of doctors and nurses to maintain the confidentiality of patient information.

Because customers are not fully satisfied with the interpersonal quality that obtained at the outpatient installation service of hospital eye Undaan, it needs to improve the quality especially in the responsiveness aspect with accelerate the long service waiting time by adding medical personnel, non-medical personnel, rooms and tools that support polyclinics services in order to serve more patients at the same time, while aspects that have achieved satisfaction needs to be retained.

\section{REFERENCE}

Alrubaiee, L., 2011. The Mediating Effect of Patient Satisfaction in the Patients' Perceptions of Healthcare Quality - Patient Trust Relationship. International Journal of Marketing Studies, 3(1), pp.103127.https://doi.org/10.5539/ijms.v3 n1p103

Aziza, R.K.., 2016. Hubungan antara Persepsi terhadap Kualitas Layanan Kesehatan dan Kepuasan Pasien di Rumah Sakit. Universitas Islam Indonesia.

Berry, L.L., Parasuraman, A., Zeithaml, V.., 1994. Improving Service Quality in America: Lessons Learned. Academy of Management Executive, 8(2), pp.32-52. https://doi.org/10.5465/ame.1994.9 503101072
Brown, L.D., Franco, L.M., Rafeh, N., Hatzell, T., 1998. Quality Assurance of Health Care in Developing Countries. Bethesda: Quality Assurance Project.

Bustani, N.M., Rattu, A.J., Saerang, J.S.., 2015. Analisis Lama Waktu Tunggu Pelayanan Pasien Rawat Jalan di Balai Kesehatan Mata Masyarakat Propinsi Sulawesi Utara. Jurnal e-Biomedik (eBm), 3(3), pp.872-883. https://doi.org/10.35790/ebm.3.3.2 015.10456

Chang, J.T., Hays., R.D., Shekelle, P.G., MacLean, C.H., Solomon, D.H., Reuben, D.B., Roth, C.P., Kamberg, C.J., Adams, J., Young, R.T., Wenger, N.S., 2006. Patients' Global Ratings of Their Health Care Are Not Associated with the Technical Quality of Their Care. Annals of Internal Medicine, 144(9), pp.665-672. https://doi.org/10.7326/0003-4819144-9-200605020-00010

Dewi, N., Susilowati, T., Nugroho, H., 2017. Tingkat Pengetahuan tentang Kerahasiaan Dokumen Rekam Medis pada Perawat di Rumah Sakit PKU Muhammadiyah Gamping pada Tahun 2017. Jurnal Permata Indonesia, 8(2), pp.92-105.

Donabedian, A., 1988. The Quality of Care:How Can It Be Assessed. JAMA， 260(12), pp.1743-1748. https://doi.org/10.1001/jama.260.1 2.1743

Feinstein, L., Sabates, R., Anderson, T.M., Sorhaindo, A., Hammond, C., 2006. Measuring The Effects of Education on Helath and Civic Engagement: Proceedings of The Copenhagen Symposium. Paris: OECD.

Fourianalistyawati, E., 2012. Komunikasi yang Relevan dan Efektif antara Dokter dan Pasien. Jurnal Psikogenesis, 1(1), pp.82-87.

Ghoniyah, N., 2012. Perilaku Komplain dan Pengaruhnya terhadap 
Kepuasan dan Loyalitas Pelanggan Jasa. Dharma Ekonomi STIE Dharmaputra Semarang.

Handayani, D.., 2012. Pemanfaatan Pos Pembinaan Terpadu oleh Lanjut Usia di Kecamatan Ciomas Kabupaten Bogor Tahun 2012 dan Faktor yang Berhubungan. Universitas Indonesia.

Handayani, S., 2016. Tingkat Kepuasan Pasien terhadap Pelayanan Kesehatan di Puskesmas Baturetno. PROFESI, 14(1), pp.42-48. https://doi.org/10.26576/profesi.13 5

Ismawati, W., 2009. Kepuasan Pasien Ditinjau dari Orientasi Komunikasi Dokter. Universitas Muhammadiyah Surakarta.

Kiguli, J., Ekirapa-Kiracho, E., Okui, O., Mutebi, A., MacGregor, H., Pariyo, G.W., 2009. Increasing Access to Quality Health Care for The Poor: Community Perceptions on Quality Care in Uganda. Patients Preferences and Adherence, 3, pp.77-85. https://doi.org/10.2147/PPA.S4091

Lestari, S., M., 2013. Penyakit Mata di Indonesia Tahun 1967-1980. VERLEDEN: Jurnal Kesejarahan, 3(1), pp.11-20.

Mosadeghrad, A.M., 2012. A Conceptual Framework for Quality of Care. Mat Soc Med, 24(4), pp.251-261. https://doi.org/10.5455/msm.2012. 24.251-261

Offei, A.K., Bannerman, C., Kyeremeh, K., 2004. Healthcare Quality Assurance Manual for Sub-Districts July 2004. Ghana: Ghana Health Service.

Piligrimiene, Z., Rutelione, A., 2013. Dual Sides of Health Care Service Quality: What is Really Important for Patients? Economics and Management, 18(1), pp.112-123. https://doi.org/10.5755/j01.em.18.1 .4233

Rahmawati, M.L.A., 2010. Hubungan antara Usia dengan Prevalensi Dugaan Mati Mendadak. Universitas Sebelas Maret.

Ruditya, A.N., Chalidyanto, D., 2015. Hubungan Karakteristik Individu terhadap Penilaian Kualitas Produk Apotek Rawat Jalan. Jurnal Administrasi Kesehatan Indonesia, 3(2), pp.108-117. https://doi.org/10.20473/jaki.v3i2.2 015.108-117

Rusmawati, A., 2016. Upaya Meningkatkan Kemampuan Perawat dalam Menerapkan Patient Centered Care (PCC) di Rumah Sakit. Universitas Diponegoro.

Saifulloh, B.H., 2014. Pengaruh Persepsi Kualitas Layanan dan Variabel Demografis terhadap Kepuasan Konsumen Transjakarta. Universitas Islam Negeri Syarif Hidayatullah Jakarta.

Silva, A.., 2000. A Framework for Measuring Responsiveness: Issue 32 of GPE Discussion Paper. Geneva: World Health Organization.

Singh, J.A., 1989. Patient Satisfaction Concept: A Review and A Reconceptualization. Advances in Consumer Research.

Thawesaengskulthai, N., Wongrukmit, P., Dahlgaard, J.J., 2015. Hospital Service Quality Measurement Models: Patients from Asia, Europe, Australia, and America. Total Quality Management and Business Excellence, (26), pp.10291041.https://doi.org/10.1080/14783 363.2015.1068596

Ummah, A,R., Supriyanto, S., 2014. Analisis Mutu Pelayanan Kesehatan berdasarkan Dimensi Dabholkar di Paviliun Mina Rumah Sakit Siti Khodijah Sepanjang. Jurnal Administrasi Kesehatan Indonesia, 2(1), pp.1-1.

Yarimoglu, E.K., 2014. A Review on Dimensions of Service Quality 
Models. Journal of Marketing Management, 2(2), pp.79-83.

Yegon, C.W.K., 2011. Patient Factors Influencing Satisfaction with Quality of Healthcare in Kenya: A Comparison of Ordered Logit and Ordered Probit Regression Models. University of Nairobi.
Yoga, I.M.S., Warmika, G.., 2013. Hubungan Karakteristik Demografi dengan Perilaku Keluhan Konsumen. E-Jurnal Manajemen Universitas Udayana, 2(9), pp.1106-1124. 